\title{
KONSEP LIMITED LEABILITY SEBAGAI BADAN HUKUM KORPORASI
}

\author{
Burhanuddin Susamto \\ Fakultas Syariah UIN Maulana Malik Ibrahim Malang \\ Email: burhanuddins.uin@gmail.com
}

\begin{abstract}
Abstrak
A strong awareness to reassert Islamic identity has emerged in these recent decades. One of the awareness is that the force of some muslim communities to internalize Islamic principles into all institutions. Nyazee, in his work, questions and also explains Islamic principles that must be the base of business organization particularly in corporation scope. The aim of this study is to show the argumentation of Islamize modern business corporation and to offer the way to realize the aim. Therefore, this study needs comprehensive and integrative way based on Islamic law towards liability limited concept as corporate law institution.

Pada dekade belakangan ini telah muncul kesadaran yang kuat untuk menegaskan kembali identitas Islam. Salah satu wujudnya adalah desakan sebagian kaum Muslimin yang menghendaki agar semua institusi kehidupan disesuaikan dengan prinsipprinsip Islam. Nyazee sendiri dalam karyanya sangat mempertanyakan dan berusaha menjelaskan prinsip-prinsip Islam yang seharusnya menjadi dasar organisasi bisnis terutama dalam lingkup korporasi. Tujuan dari studi ini adalah untuk menunjukkan mengapa korporasi bisnis modern perlu di-Islamisasi, dan menawarkan bagaimana cara tersebut dapat terwujud. Karena itu untuk mencapai tujuan itu, studi ini membutuhkan upaya yang konprehensif dan terintegrasi menurut Hukum Islam terhadap konsep limited liability sebagai badan hukum korporasi.
\end{abstract}

Kata Kunci: Korporasi, Limited Liability, Badan Hukum

Pengembangan body of knowledge terkait hukum ekonomi Islam dan bisnis syari'ah merupakan suatu keniscayaan. Terlepas dari pro dan kontra, salah satu ilmuwan hukum Islam abad modern yang perlu ditelaah adalah pemikiran Imran Ahsan Khan Nyazee. ${ }^{1}$ Melalui karya berjudul: Islamic Law of Business Organization

1 Imran Ahsan Khan Nyazee adalah seorang professor dari Fakultas Syariah dan Hukum di Islamabad, Pakistan. Dia memperoleh pendidikan sarjana hukum (L.LB) dari Punjab University pada 1969. Kemudian di tahun 1983, beliau mendapatkan penghargaan mendali emas untuk keahliaanya di bidang hukum (L.LM) dari the International Islamic University of Michigan Law School, Ann Arbor, USA.
(Corporation) (1998) dan tulisan lain yang terkait, ${ }^{2}$ dia mencoba untuk menganalisis keabsahan korporasi dari sudut pandang hukum Islam, ${ }^{3}$ sebelum menawarkan pemikiran baru tentang pentingnya Islamisasi korporasi dalam bisnis modern.

2 Karya Imran Ahsan Khan Nyazee yang terkait antara lain, Islamic Law of Business Organization: Partnership (Pakistan: The International of Islamic Thought, 2000); Theories of Islamic Law (Pakistan: The International of Islamic Thought and Islamic Research Institute, 1994); The Concept of Riba and Islamic Banking (Islamabad: Nazi Publishing House, 1995).

3 Taqiyuddin an-Nabhani, An-Nizâm alIqtishâdi fi al-Islâmi (Beirut: Darul Ummah, 2004), h. 88; Ahmad Mahmud As-Sabatin, Al-Buyû' al-Qadîmah wa al-Mu'âshirah wa al-Burshat al-Mahalliyyah wa adDuwaliwyah (Beiruth Darul Bayariq, 2002), h. 60. 
Menurut Nyazee, ${ }^{4}$ korporasi merupakan suatu perusahaan joint stock yang para anggotanya memiliki tanggung jawab terbatas pada penyertaan modal mereka. Korporasi sebagai perusahaan raksasa, tentu memiliki dampak besar terhadap perekonomian suatu negara. Apabila dikelola dengan baik, keberadaan korporasi akan banyak memberikan kemaslahatan. Begitupula sebaliknya, apabila korporasi tidak dikelola dengan baik, sudah pasti akan menimbulkan kemudharatan. Karena itu, sebagai kelanjutan dari buku sebelumnya, Islamic Law of Business Organization: Partnership (1997), Nyazee berupaya menerapkan konsep-konsep esensial untuk menelaah secara kritis praktik korporasi dari sudut padang hukum Islam.

Dari segi prakteknya, hampir semua korporasi modern terbentuk tanpa mendasarkan pada prinsip-prinsip syari'ah. Meskipun demikian, keberadaanya masih tetap saja berjalan, bahkan tidak hanya di negara-negara Barat, tetapi juga di dunia Islam. Kenyataan inilah yang memaksa para ilmuwan Muslim untuk meneliti keabsahanya melalui perspektif hukum Islam secara lebih lanjut. Dari berbagai aspek korporasi yang dapat ditinjau dari perspektif hukum Islam untuk mententukan keabsahan itu, diantaranya tentang pemberlakuan konsep limited leability.

Dalam hukum Islam, secara langsung tidak dijumpai istilah limited liability sebagaimana dikenal dalam hukum modern yang mengatur tentang korporasi. Konsep limited leability merupakan bentuk tanggung jawab yang terbatas pada modal penyertaan (saham). Perusahaan yang mengadopsi konsep ini lazim dikenal dengan sebutan Perseoran Terbatas (PT), sebagai salah satu bentuk badan hukum. Dalam Pasal 3 ayat (1) UUPT dinyatakan: "Pemegang saham perseroan tidak bertanggung jawab secara pribadi atas perikatan yang dibuat atas nama perseroan dan tidak bertanggung jawab atas

4 Imran Ahsan Khan Nyazee, Islamic Law of Business Organization (Corporation) (Pakistan: The International of Islamic Thought, 1998), h. 123. kerugian perseroan melebihi saham yang dimiliki." Jadi sesuai namanya, keterlibatan dan pertangungjawaban para pemilik PT hanya terbatas pada saham yang dimiliki. Perseroan terbatas sendiri juga mempunyai kaitan dengan bursa efek. Kaitannya adalah apabila sebuah perseroan terbatas telah menerbitkan sahamnya untuk publik (go public) melalui bursa efek, maka perseroan itu dikatakan telah menjadi "perseroan terbatas terbuka" (Tbk).

Menurut Nyazee, korporasi bisnis dikombinasikan dengan konsep limited liability, juga merupakan sebuah alat yang digunakan untuk melipatgandakan modal. ${ }^{5}$ Pendapat ini sepertinya terinspirasi dari pemikiran Posner melalui karyanya, Economic Analysis of Law, yang menyatakan: "....The corporation is primarily a method of solving problems encountered in raising substantial amount of capital." ${ }^{6}$ Mungkin karena alasan itu sebagian besar ilmuwan muslim benarbenar antusias untuk menerima konsep tersebut, meskipun pada sisi lain dituntut untuk mentaati norma-norma syari'ah. Kenyataan inilah yang menjadi alasan perlunya Islamisasi korporasi seperti halnya bisnis perbankan dan perekonomian secara keseluruhan. Namun yang menjadi pertanyaan, apakah korporasi bisnis modern telah menyalahi prinsip-prinsip syari'ah, sehingga perlu upaya Islamisasi?

Pada hukum bisnis modern, persoalan terkait limited liability dalam korporasi merupakan tema yang penting. Hampir semua perusahaan bisnis modern menjadikan konsep limited liability sebagai bentuk badan hukum. Bagaimana tinjauan hukum Islam terhadap limited liability sebagai badan hukum korporasi, merupakan tema menarik untuk diteliti. Karenanya sebelum ditempuh langkah lebih lanjut terkait upaya Islamisasi, pembahasan untuk mengetahui keabsahan limited liability perlu dilakukan terlebih dahulu. Namun agar tujuan tersebut dapat tercapai, mempelajari prinsip-prin-

\footnotetext{
$5 \quad$ Imran Ahsan Khan Nyazee, Islamic., h. 9.

6 Richad A. Posner, Economic Analysis of Law (Boston: Little Browntand Company, t.t.), h. 290.
} 
sip hukum Islam yang terkait dengan persoalan korporasi menurutnya harus dilakukan secara menyeluruh. Karena itu, mengetahui bagaimana pandangan Nyazee tentang konsep limited liability sebagai badan hukum korporasi merupakan tujuan utama dari pembahasan ini.

\section{Limited Liability Sebagai Badan Hukum}

Hans Kalsen sebagaimana dikutip Nyazee, menyatakan bahwa konsep limited leability muncul dari adanya konsep badan hukum. ${ }^{7}$ Istilah badan hukum dalam fiqh disebut dengan shakhsîyah i'tibâriyah, ${ }^{8}$ sebagai kebalikan dari manusia dalam pengertian hakiki (shakhsiyah haqîqîyah). Dalam suatu korporasi modern, badan hukum biasanya akan bertindak sebagai subjek hukum yang berwenang untuk menjalankan hak dan kewajiban bisnis. Karena itu sebelum mengkaji keabsahan limited liability secara lebih lanjut, mengetahui sekilas pandangan hukum Islam terhadap badan hukum merupakan hal yang penting dalam pembahasan ini.

Isa Abduh dalam bukunya yang berjudul, Al-'Uqûd al-Syar'îyah al-Hâkimah, sebagaimana dikutip oleh Nyazee menyatakan: “...telah menjadi kesepakatan bahwa badan hukum tidak dikenal dalam khazanah Islam. Meskipun demikian, teks-teks arab dan diantara umat Islam berpendapat kalau konsep itu dapat ditetapkan." ${ }^{9}$ Kecendrungan menerima badan hukum, menurut Nyazee telah berakibat penerimaan terhadap konsep limited liability, seperti ditunjukkan oleh Accounting Standards Board yang menyatakan: "..... There is no objection in shari'ah to setting up a company whose liability is limited to its capital for that is known to the company clientele and such awareness on their part precludes deception." 10

7 Hans Kelsen, General Theory of Law and State (Tp: Trans Wedberg, 1945), h. 92.

8 Muhammad Hasbi Ash-Shiddiqy, Pengantar Figh Muamalah (Semarang: Pustaka Rizki Putra, 2001), h. 197.

9 Isa Abduh, Al-'Uqûd al-Syar'îyah al-Hâkimah (Kairo: Dal al-I'tisam, 1977), h. 25.

10 Financial Accounting Standards Board, Objects and Concepts of Financial Accounting, Presentation
Dalam bukunya, Principles of Islamic Jurisprudence, Abdur Rahim seperti dikutip Nyazee, menyatakan: "Masih belum jelas, apakah fuqaha salaf menerima badan hukum (juristic person)....kalau fuqaha khalaf cendrung menerimanya." Penemuannya tentang pandangan fuqaha khalaf nampaknya didasarkan pada pembahasan mereka tentang institusi waqf. ${ }^{11}$ Dari hasil penelitian Nyazee, konsep badan hukum dapat ditemukan dalam karya 'Abd al-Qadir Awdah. Melalui bukunya berjudul, al-Tashrî al-Jinầi al-Islamî. Awdah menyatakan bahwa syari'ah sejak mulanya mengakui badan hukum. Para fuqaha menganggap bayt almâl, waqf adalah sebagai badan hukum. Begitupula dengan institusi lainnya, misalnya madrasah-madrasah, rumah sakit, dan lain sebagainya.... ${ }^{12}$ Pandangan ini dapat diterima dengan mudah oleh banyak fuqaha modern (khalaf), mulai dari Musthafa Ahmad al-Zarqa, ${ }^{13}$ karena menurut Nyazee adanya pengaruh dari kebesaran namanya.

Menurut 'Ali al-Khafif, seorang ulama Mesir yang dikutip Nyazee mengatakan, bahwa konsep dhimmah dan ketentuan yang mengaturnya adalah hanya persoalan reorganisasi sehingga tidak perlu ijtihâd. Tidak ada ayat al-Qur'an dan Hadits yang menolak justifikasi badan hukum sebagai sesuatu yang non-manusia. ${ }^{14}$ Meskipun demikian, nampaknya Nyazee tidak sependapat dengannya, karena pemberian status subjek hukum bagi non-manusia adalah sesuatu yang sulit dalam hukum Islam. Alasannya, apabila perintah dikaitkan dengan ibadah, maka badan hukum sebagai shakhsîyah i'tibâriyah tentu tidak dapat menjalankannya. ${ }^{15}$ Namun sepertinya Nyazee lupa, meskipun badan hukum berlaku, tentu perhitungan amal perbuatan secara vertikal tetap dikembalikan kepada pribadi

and General Disclosure Standart and Information about the Organization (Jeddah: 1994), h. 50.

11 Nyazee, Islamic Law., h. 89.

12 Abd al-Qadir Awdah, Al-Tashrîal-Jinâ'î alIslamî (Beirut: al-Muassasat ar-Risalah,1992), h. 393.

13 Musthafa Ahmad al-Zarqa, Al-Madkhâl AlFighî 'Al-'Aam (Beirut: Darul al-Fikr, t.t), h. 253.

14 Al-Khafif, Al-Syarikât fíal-Figh al-Islâmî (Kairo: tp, t.t.), h. 25.

15 CrAsyazeerjtt'slamic Law., h. 92. 
masing-masing. ${ }^{16}$ Kedudukan manusia secara hakiki dalam hal ini adalah sebagai wakil korporasi untuk menjalankan hak dan kewajiban sesuai dengan akad yang digunakan. ${ }^{17}$

\section{Hukum Limited Liability}

Untukmenghadapiperkembangan pasar yang berbasis bunga (riba), para ilmuwan Muslim belum cukup hanya membentuk institusi keuangan yang mendasarkan pada akad-akad tertentu, melainkan harus diikuti upaya Islamisasi terhadap korporasi. Untuk menganalisis struktur korporasi bisnis modern, Nyazee menganjurkan membuat verifikasi bentuk kontrak yang terjalin antara shareholder dengan korporasi. Bila bentuk kontrak antara shareholder dan korporasi telah dianalisis, kemudian keduanya perlu dikomparasikan dengan akad-akad yang terdapat dalam fiqh. Hasil analisis terhadap kontrak tersebut harus dapat mengungkap bagaimana status limited/ unlimited liability menurut pandangan hukum Islam. Karenanya untuk menentukan keabsahannya secara lebih lanjut, Nyazee menawarkan dua prinsip utama, yaitu pelarangan riba dan al-kharâj bi al-damân. ${ }^{18}$ Namun yang menjadi pertanyaan, mengapa konsep korporasi bisnis selama ini tidak ditelaah berdasakan ke-

16 Tiap-tiap diri bertanggung jawab atas apa yang telah diperbuatnya (QS.Al-Muddatsir [74]:38).

17 Apabilakorporasididirikanolehsekelompok orang yang terlibat langsung dalam manajemen berdasarkan sistem profit/loss sharing, maka akad yang digunakan adalah musyarakah (sharikâh). Jika jumlah modal yang disertakan pendiri sama (Rp.X + Rp.X), maka akad yang digunakan sharikâh al-mufâwuadah. Sedangkan jika modal yang disertakan berbeda (Rp.X + Rp.Y), maka akad yang digunakan sharikâh al-'inân. Dalam hal ini, apabila korporasi mengangkat pekerja (karyawan) dengan sistem upah ('ujrah) bulanan, maka akad yang digunakan ija>rah. Kemudian, apabila korporasi menjalin kerjasa sama bagi hasil dengan para shareholder (pemegang saham) yang tidak terlibat langsung dalam manajemen, berarti akad yang digunakan mudlârabah, serta lain-lain secara kombinasi sesuai tujuan yang akan dicapai. Hak dan kewajiban horizontal yang timbul dari perikatan ditentukan berdasarkan rukun dan syarat akad yang digunakan, meskipun perbuatan masingmasing individu secara vertical tetap dikembalikan kepada Allah.

18 Nyazee, Islamic Law., h. 10. dua prinsip itu $?^{19}$ Jawabannya adalah, bahwa sebagian besar ulama kontemporer dalam menerima konsep korporasi karena cendrung mengedepankan kaidah fiqh yang menegaskan:

$$
\text { 20. الأصل في الأشياء الإباحة مالم يرد دليل التحريم }
$$

Kaidah tersebut menurut Nyazee telah menjadi dasar berfikir sebagian besar ulama kontemporer untuk menerima konsep korporasi, terutama selama dalam menjalankan usahanya tidak bertentangan dengan prinsip-prinsip syari'ah. Riba sebagai salahsatubentukkeharaman, terbukticukup mendapatkan banyak perhatian ulama. Adiwarman A. Karim dalam bukunya, Bank Islam: Analisis Figh dan Keuangan, menyatakan bahwa riba dapat terjadi karena melanggar kaidah al-kharâj bi al-damân, ${ }^{21}$ yaitu ketika kreditor mensyaratkan pembayaran bunga untuk mendapatkan keuntungan yang bersifat pasti (fixed and predetermined rate). Namun oleh Nyazee, kaidah itu lebih banyak digunakan untuk mengkritisi konsep pembatasan tangung jawab terhadap risiko (limited liability) yang berlaku dalam korporasi.

Keabsahan institusi yang memiliki signifikansi bagi masyarakat hanya dipersoalkan bila prinsip-prinsip yang dilanggar adalah sangat mendasar bagi sistem, sehingga prosesnya berpotensi menyalahi sebagian besar ketentuan syari'at Islam. Menurut Nyazee, jika limited liability hanya sebagai konsep prosedural, maka proses Islamisasi terhadap korporasi hanya membutuhkan sedikit perubahan. Tetapi jika limited liability pelanggarannya telah menyentuh hal-hal prinsip, berarti upaya Islamisasi korporsi hingga aspek yang mendasar menjadi relevan adanya.

19 Kalangan fuqaha menambahkan sejumlah prinsip pelarangan adanya gharar. Namun dalam pandangan Nyazee, urgensi prinsip gharar dan jahâlah masih di bawah kedua prinsip tersebut, dan tidak begitu berpengaruh dalam hukum dagang Islam. Sudah tentu ada berbagai prinsip lainnya yang diterapkan dalam suatu perjanjian, namun prinsip riba dan damân adalah dua prinsip yang membedakan hukum kontrak Islam dengan perjanjian kontrak dengan sistem lainnya.

20 Nyazee, Islamic Law., h. 11.

21 Adiwarman A. Karim, Bank Islam: Analisis Figh dan Keyangaga (Jakkarta: Rajawali Press, 2004), h. 38.

\section{(n) nitro ${ }^{\text {PDF }^{\prime}}$ professional}


Dalam struktur korporasi modern, para shareholder dan perusahaan dipisahkan oleh badan hukum yang dibentuk melalui undang-undang. Akibat pemisahan tersebut, tanggungjawab anggota korporasi/shareholder menjadi terbatas sesuai dengan penyertaan modal. Artinya, diantara keduanya tidak ada tanggung jawab langsung sebagaimana kontrak agensi (wakalah). Apabila hubungan antara shareholder dengan korporasi didasarkan atas akad wakalah, maka pembatasan tanggung jawab shareholder (limited liability) terhadap hutang-hutang korporasi maupun obligasi lainnya menurut Nyazee menjadi tidak berlaku.

Nyazee berpandangan, bahwa korporasi modern adalah cara lain untuk menciptakan hubungan kreditor-debitur guna memperoleh pemasukan yang relatif bebas resiko dari modal seseorang. Kenyataannya, bersama-sama dengan sistem ekonomi berbasis bunga (interest), keberadaan korporasi telah membentuk fondasi kapitalisme. Dikatakan demikian, karena kapitalisme melalui institusi-institusi finansial telah memberlakukan sistem bunga (riba) dalam memberikan pinjaman. ${ }^{22}$ Sedangkan cara lainnya adalah melalui investasi langsung ke dalam korporasi yang menggunakan konsep limited liability untuk mengalihkan resiko kredit kepada pihak ketiga. ${ }^{23}$ Pendapat ini sepertinya dipengaruhi oleh pemikiran Posner yang menyatakan:

Limited liability is a means not of eliminating the risks of entrepreneurial failure, but shifting them from individual investors to the voluntary and involuntary creditors of the corporation - it is they who bear the risks of corporate default. ${ }^{24}$

Meskipun institusi finansial menjadi kreditor sukarela, namun menurut Nyazee, sebagai pengganti untuk menghindari kesulitan pengalihan limited liability dari para shareholder, mereka memberlakukan sistem

22 Misalnya yang paling dominan adalah melalui sistem kredit berbasis bunga di lembaga perbankan konvensional.

23 Nyazee, Islamic Law., h. 294-295.

24 Richard A. Posner, Economic Analysis of Law (Boston: Little, Brown and Company, t.t.), h. 142. jaminan (hipotik) atau pungutan-pungutan lain ${ }^{25}$ secara langsung dari asset-aset perusahaan. ${ }^{26}$ Kalaupun limited liability dipandang bisa diterapkan dalam korporasi baru berdasarkan prinsip-prinsip hukum Islam, namun ide pengalihan tanggung jawab kepada orang-orang yang seharusnya tidak menanggung beban tersebut, nampaknya tidak Islami. ${ }^{27}$ Hukum Islam melalui prinsip larangan riba dan al-kharâj bi aldamân, berupaya menawarkan suatu sistem persamaan dalam menganggung risiko, sehingga pada gilirannya dapat menciptakan distribusi kekayaan secara adil. ${ }^{28}$

Nyazee berpandangan, bahwa larangan riba merupakan konsep yang sudah jelas dalam al-Quran dan Sunnah. Begitu pula dengan prinsip al-kharâj bi al-damân yang berasal dari Sunnah Nabi, merupakan bagian kaidah hukum Islam sudah banyak diterima secara luas oleh para fuqaha. Kedua prinsip itu meskipun sudah banyak digunakan oleh ilmuwan Muslim dalam melakukan Islamisasi pada institusi keuangan, namun belum banyak digunakan untuk menganalisis konsep limited liability dalam korporasi. Kenyataan inilah yang menjadi alasan Nyazee melakukan kritikan terhadap penerimaan konsep limited liability oleh para ilmuwan Muslim.

Justifikasi konsep limited liability yang munculdalam pikiranmerekaadalahkarena keberadaanya dianggap sebagai alat sosial yang menggiring kepada pengembangan kesejahteraan umat secara keseluruhan. ${ }^{29}$ Padahal pemberian persetujuan korporasi hanya berdasarkan prinsip kebolehan (alasl fî al-ashyâ al-ibâhah) menurut Nyazee adalah tidak cukup dan bahkan mungkin menjadi sebuah pendekatan yang defektif. ${ }^{30}$ Kurangnya pendekatan yang

25 Misalnya melalui bunga pinjaman (interest) yang hukumnya riba menurut pandangan hukum Islam.

26 Nyazee, Islamic Law., h. 185.

27 Nyazee, Islamic Law., h. 189.

28 Nyazee, Islamic Law., h. 188.

29 Muhammad Taqi Usmani, "The Principle of Limited Liability From the Shariah Viewpoint", New Horizon (Agust-Sept 1992), h. 22.

30 CrNyazee, İlamic Law., h. 11. 
menyeluruh menurutnya hanya akan mengakibatkan adanya pendapat-pendapat yang tidak konsisten. Karenanya, Nyazee berpandangan bahwa persoalan mengenai limited/ unlimited liability tidak akan dapat dipahami secara baik, kecuali bila ketentuan tentang kredit dan tanggung jawabnya yang terdapat dalam hukum Islam diklarifikasi lebih dulu. ${ }^{31}$

Dengan mendasarkan kaidah fiqh, semua bentuk keuntungan menurut hukum Islam harus didasarkan atas prinsip liability (damân). Ulama Hanifiyah, sebagaimana dikutip Nyazee, membagi damân ke dalam tiga macam, yaitu (1) Damân al-mâl, yaitu tanggung jawab untuk menanggung kerugian yang wujudnya berupa harta kekayaan. Harta kekayaan ini dapat berupa modal yang disertakan untuk menghadapi kemungkinan adanya klaim-klaim terhadap hutang perseroan; (2) Damân al-'amal, yaitu tanggung jawab untuk menyelesaikan suatu pekerjaan; dan (2) Damân al-tsaman, yaitu tanggung jawab untuk melakukan pembayaran-pembayaran. ${ }^{32}$ Namun apakah liability itu bersifat terbatas atau tidak terbatas, sepertinya belum ada penjelasan lebih lanjut dalam fiqh, sehingga menimbulkan pro dan kontra.

Pada karya-karya terdahulu, maupun yang ditulis oleh para ilmuwan modern, telah dinyatakan bahwa dasar pertama untuk memperoleh keuntungan adalah harta (almâl). Meskipun pendapat itu benar, namun menurut Nyazee penelitian yang lebih mendalam menunjukkan bahwa pernyataan ini tidak menyelesaikan seluruh konsep. Al-mâl saja tidak cukup untuk memiliki hak atas keuntungan, namun harus disertai dengan suatu liability untuk menanggung kerugian (al-damân). Syarat utama damân terhadap kepemilikan harta menurut Nyazee adalah harus tetap dikuasai oleh investor setiap waktu. Karena itu, apabila kepemilikan ini diberikan kepada orang lain, maka dengan sendirinya damân ikut berpindah. Pemikiran ini sebenarnya sejalan dengan

31 Nyazee, Islamic Law., h. 25.

32 Nyazee, Islamic Law., h. 53. akad mudârabah yang menempatkan risiko modal kepada shahib al-mâl dan risiko kerja kepada mudârib. Tetapi apabila korporasi diidentikan dengan muda>rib atau wakil apabila akadnya wakâlah, sedangkan shareholder sebagai shahib al-mâl yang masing-masing memiliki tanggung jawab terbatas terhadap damân tentu tidak tepat. Dikatakan demikian, karena bagaimanapun dalam korporasi memiliki pola hubungannya yang bersifat kompleks sehingga membutuhkan kombinasi dari berbagai akad.

Dalam institusi bisnis modern, konsep limited liability telah menjadi bagian dari pembentukan korporasi. Selama ini limited liability dipahami sebagai bentuk pembatasan tanggung jawab terhadap pelunasan hutang-hutang dari seluruh aset perusahaan, termasuk keuntungan atau segala sesuatu yang ada setelah kebangkrutan. Namun menurut Nyazee, konsep pembatasan tanggung jawab yang melekat pada shareholder adalah tidak benar. Karena menurutnya, korporasilah yang berhutang kepada shareholder sesuai denganjumlah penyertaan masing-masing. Dari penyertaan itulah, para shareholder patut memiliki klaim atas aset korporasi berdasarkan sertifikat kerjasama yang mereka pegang. Sebab itu, apabila shareholder memiliki limited liability, seharusnya pemegang obligasi (bond holder) juga memiliki limited liability sejauh obligasi (bonds) mereka. ${ }^{33}$

Dalam hal ini, sepertinya Nyazee akan menyamakan kepemilikan saham dengan obligasi yang sebenarnya berbeda. Saham adalahsuratberhargayangmerupakantanda penyertaan modal pada perusahaan yang menerbitkan saham tersebut. ${ }^{34}$ Sedangkan obligasi (bonds, as-sanadat) adalah bukti pengakuan utang dari perusahaan (emiten) kepada para pemegang obligasi yang bersangkutan. ${ }^{35}$ Disamping itu, bukankah

33 Nyazee, Islamic Law., h. 67.

34 Dalam Keppres RI No. 60 tahun 1988 tentang Pasar Modal, saham didefinisikan sebagai surat berharga yang merupakan tanda penyertaan modal pada perseroan terbatas sebagaimana diatur dalam KUHD (Kitab Undang-Undang Hukum Dagang atau Staatbald No. 23 Tahun 1847).

35 Siahaan \& Manurung, Aktiva Derivatif: Pasar Uang, Pasar Modal, Pasar Komoditi, dan Indeks (Jakarta: 
shareholder juga bisa menjadi satu kesatuan yang tidak terpisah dengan korporasi, apalagi jika shareholder berkedudukan sebagai pemegang saham pengendali. Karenanya pada dasarnya yang menjadi persoalan adalah, jika hutang korporasi ternyata lebih besar dari modal saham yang disertakan (pailit) siapa yang harus mempertangung jawabkan? Kemudian apabila hutang tersebut tidak dilunasi, bagaimana hukumnya menurut pandangan syari'at Islam?

Parafuqaha kontemporersepakat, bahwa haram hukumnya memperdagangkan saham di pasar modal dari perusahaan yang bergerak di bidang usaha yang haram. ${ }^{36}$ Namun, jika saham yang diperdagangkan di pasar modal itu adalah dari perusahaan yang bergerak di bidang usaha halal, maka hukumnya boleh secara syar'i. Alasan yang menunjukkan kebolehannya adalah semua dalil yang menunjukkan bolehnya aktivitas tersebut. ${ }^{37}$ Namun demikian, ada fuqaha yang tetap mengharamkan jual-beli saham walaupun dari perusahaan yang bidang usahanya halal. Misalnya, Taqiyuddin anNabhani (2004), Yusuf as-Sabatin (2002), dan Ali Ahmad as-Salus (2006). Ketiganya sama-sama menyoroti bentuk badan usaha (PT) yang sesungguhnya tidak islami. Jadi, sebelum melihat bidang usaha perusahaannya, seharusnya yang dilihat dulu adalah bentuk badan usahanya (limited liability) apakah memenuhi syarat sebagai perusahaan islami (sharikah Islâmiyah) atau tidak. $^{38}$

Konsep limited liability terhadap resiko (damân) sesuai dengan modal yang disertakan khusus bagi para invesor yang akan Elex Media Komputindo, 2006).

36 Dalil yang mengharamkan jual-beli saham perusahaan seperti ini adalah semua dalil yang mengharamkan segala aktivitas tersebut. Lihat: Syahatah Husein \& Athiyahdan Fayyadh, Bursa Efek: Tuntunan Islam dalam Transaksi di Pasar Modal, (Surabaya: Pustaka Progresif, 2004), H. 18; Yusuf Ahmad Mahmud as-Sabatin, Al-Buy $\hat{u}^{\prime}$ al-Qadîmah wa al-Mu'âshirah wa al-Burshat al-Mahalliyyah wa adDuwaliyyah, (Beirut: Darul Bayariq, 2002), h. 109.

37 Syahatah Husein \& Athiyahdan Fayyadh, Bursa Efek, h. 17.

38 M.Siddiq al-Jawi, http://hizbut-tahrir. or.id/2007/10/01/jual-beli-saham-dalam-pandanganislam/, diakses tanggal 7 Oktober 2010 mendapatkan keuntungan bisa dibenarkan secara syari'at. Pembenaran ini selain tidak bertentangan dengan prinsip al-kharâj bi aldamân, juga sesuai dengan kaidah fiqh:

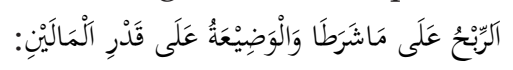

"keuntungan dibagi berdasarkan kesepakatan, sedangkan resiko kerugian ditentukan berdasarkan modal yang disertakan kedua belah pihak." Pengertian modal yang disertakan disini tentu bentuknya bermacam-macam, ada yang berupa harta dan ada yang tenaga. Keuntungan dari modal yang disertakan selain untuk dibagikan, hendaknya disimpan sebagai kepemilikan bersama (co-ownership).

Penguasaan aset korporasi oleh pemilik berbeda dengan para shareholder yang hanya berkedudukan sebagai investor. Karena itu, konsep limited liability seharusnya tidak boleh berlaku bagi para semua pihak yang berkedudukan sebagai pemilik korporasi dan/ atau shareholder yang telah mengambil alih kepemilikan tersebut setelah menjadi pemegang saham pengendali. Sebab bagaimanapun, hutang adalah hutang yang tetap harus dilunasi oleh semua pihak yang bersangkutan, meskipun hutang itu melebihi jumlah modal korporasi yang disertakan. Karena kalau pemiliknya sendiri tidak mau melunasi hutang, siapa yang bertanggung jawab?

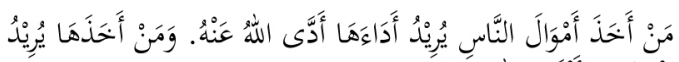

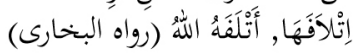

Barangsiapa yang mengambil harta manusia (hutang) agar dia menunaikan kewajibannya, niscaya Allah memenuhinya. Dan barangsiapa yang mengambilnya, tetapi dengan maksud menghabiskannya, niscaya Allah akan menghabiskannya (HR. Bukhari).

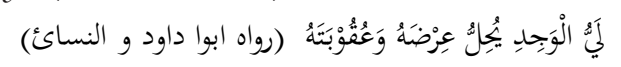

Seseorang yang telah sanggup untuk membayar kewajibannya, tetapi dilalaikan, maka boleh disita hartanya dan diberi ganjaran (HR. Abu Dawud dan Nasai').

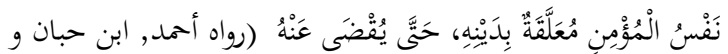

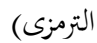

Jiwa seorang mukmin tergantung utangnya (n) nitro ${ }^{\text {PDF }^{\prime}}$ professional 
hingga dibayarkan (HR Ahmad, Ibn Majah dan At-Tirmidzi).

Bahkan sebelum sampai pada terbentuknya korporasi ada yang menyatakan, bahwa konsep limited liability hukumnya haram. Taqiyuddin an-Nabhani dalam $A n-$ Nizâm al-Iqtishâdi fi al-Islâm menegaskan bahwa perseroan terbatas (limited liability) adalah bentuk perseroan yang batil (tidak sah), karena bertentangan dengan hukum-hukum sharikâh dalam Islam. ${ }^{39}$ Kebatilannya antara lain dikarenakan dalam limited liability tidak terdapat ijab dan qabul sebagaimana dalam akad sharikâh. Pada konsep itu yang ada hanyalah transaksi sepihak dari para investor yang menyertakan modalnya dengan cara membeli saham dari perusahaan atau dari pihak lain di pasar modal, tanpa ada perundingan atau negosiasi apapun baik dengan pihak perusahaan maupun pesero (investor) lainnya. ${ }^{40}$

Berbeda dengan pendapat ilmuwan modern lainnya, korporasi bisnis selain tidak menyalahi prinsip-prinsip syari'ah, juga tidak bertentangan dengan ketentuanketentuan fiqh. ${ }^{41}$ Ini berarti limited leability yang menjadi bagian dari pendirian korporasi juga tidak dianggap bertentangan dengan prinsip-prinsip syari'ah. Pendapatpendapat paling terkenal yang dikritisi Nyazee adalah resolusi No.7/1/65 Tahun 1992 yang dikeluarkan oleh Islamic Fiqh Academy adalah mengenai limited leability dan validitas dari kerjasama perusahaan (sharikâh al-musâhamah). Bahkan selain pendapat itu, sejumlah ilmuwan juga telah menyuarakan kebolehan limited leability bagi para shareholder, diantaranya adalah SM. Hasanuzzaman, Muhammad Taqi Usmani, Ali Muhiy al-Din Raghi dan al-Marzuqi al-

39 Taqiyuddin an-Nabhani, An-Nizâm alIqtishâdi fi al-Islâm (Beirut: Darul Ummah, 2004), h. 153.

40 M.Siddiq al-Jawi, http://hizbut-tahrir. or.id/2007/10/01/jual-beli-saham-dalam-pandanganislam/, diakses tanggal 7 Oktober 2010

41 Ali Muhiy al-Din Raghi, Al-Aswâq al-Mâlîyah fi Mîzân al-Fiqh al-Islâmî, Islamic Fiqh Academy, Majma' al-Figh al-Islâmî (Jeddah, 1992), h. 85.
Biqami. ${ }^{42}$ Adapun diantara asumsi-asumsi yang mendapat kritikan Nyazee adalah sebagai berikut: (1) Hukum Islam menerima konsep badan hukum, misalnya waqf dan baytal-mâl, karena itu penerimaan korporasi modern sebagai badan hukum adalah dapat diterima. ${ }^{43}$ (2) Korporasi dibentuk melalui akad sharikâh dengan para shareholder. Sedangkan menurut Nyazee korporasi dibentuk berdasarkan akad wakalah.; (3) Profit sharing dalam korporasi adalah sah menurut hukum Islam, sebab kerjasama itu merepresentasikan kepemilikan korporasi oleh shareholder yang merupakan sebuah sharikâh; ${ }^{44}(3)$ Limited liability dapat diterima hukum Islam, sebagai sebuah keharusan dalam bisnis modern; dan (4) Korporasi diperbolehkan mengajukan pinjaman, namun akan lebih baik bila seluruh kebetuhan-kebutuhan pembiayaan dilakukan berdasarkan pembiayaan yang seimbang. ${ }^{45}$

Nyazee menyayangkan, bahwa sebagian besar asumsi tersebut tidak mendasarkan pada pengamatan menyeluruh terhadap prinsip-prinsiphukumIslam.Parapenyusun opini itu tidak mengkaitkan alasan mereka dengan prinsip-prinsip sesungguhnya yang terdapat dalam figh. Pendapat mereka menurut Nyazee, kebanyakan didasarkan pada kaidah kebolehan umum (al-ashl fî al-ashyâ al-ibâhah) yang tidak dipahami secara menyeluruh. Padahal upaya itu sangat diperlukan untuk menganalisis seluruh struktur korporasi bisnis modern berdasarkan prinsip-prinsip umum dan selanjutnya mencari model korporasi baru yang Islami.

Korporasi modern seharusnya bukan hanya menjadi instrumen keuangan untuk mendukung investasi yang relatif bebas

42 Nyazee, Islamic Law.,h. 8.

43 Ini merupakan kesimpulan dari Ali alKhafif dalam Al-Syarikât fî al-Figh al-Islâmî, dan, 'Abd al-'Aziz al-Khafif dalam Al- Syarikât

44 Lihat: Ali Muhiy al-Din Raghi, Al-Aswâq al-Mâlîyah fi Mîzân al-Figh al-Islâmî, Islamic Fiqh Academy, Majma' al-Figh al-Islâmî (Jeddah, 1992), h. $7: 1$.

45 Zabin al-Marzuqi al-baqami, Al-Sharikât al-Musâhamah fî an-Nizâm al-Sa'ûdì, (Mekah: Umul Qura' University, (986); Nyazee, Islamic Law.., h. 8. 
resiko melalui pasar modal, namun juga digunakan untuk mendukung berbagai usaha yang berbasis sektor riil. Pesatnya pertumbuhan lembaga keuangan syari'ah, apabila tidak diikuti oleh upaya pengembangan usaha di sektor riil, tentu akan menimbulkan persoalan tersendiri. Bagaimana mungkin lembaga keuangan itu melakukan investasi secara halal, apabila usaha di sektor riil yang berbasis syari'ah aja jarang dijumpai. Kenyataan, bahwa korporasi sebagai organisasi bisnis yang menjalankan usaha sekor riil, selama ini belum tersentuh aspek syari'ah sebagaimana lembaga keuangan. Persoalan inilah yang menjadi alasan Nyazee pentingnya Islamisasi korporasi. Kemudian bagaimana wujud nyata dari konsep Islamisasi korporasi itu, dalam karyanya Nyazee baru dijumpai asumsiasumsi yang masih bersifat umum.

\section{Kesimpulan}

Pada beberapa dekade belakangan telah muncul kecenderungan baru dari sebagian kaum Muslimin untuk kembali ke identitas Islam di segala aspek kehidupan.

\section{DAFTAR PUSTAKA}

Abduh, Isa. 1977. Al-'Uqûd al-Syar'îyah alHâkimah. Kairo: Dal al-I'tisam

Awdah, 'Abd al-Qadir. 1992. Al-Tashrî alJinâ'̂̂ al-Islamî. Beirut: al-Muassasat ar-Risalah

Al-Zarqa, Musthafa Ahmad, t.th. Al-Madkhal Al-Fiqhî Âl-'Aam. Beirut: Darul al-Fikr

Al-Khafif. t.th. Al-Syarikât fî al-Fiqh al-Islâmî. Kairo: tp

Al-Baqami, Zabin al-Marzuqi. 1986. AlSharikât al-Musâhamah fî an-Nizâm alSa'ûdî. Mekah: Umul Qura' University

Al-Jawi, M.Siddiq. 2007. http://hizbut-tahrir. or.id/2007/10/01/jual-beli-saham-dalampandangan-islam/, diakses tanggal 7 Oktober 2010

An-Nabhani, Taqiyuddin. 2004. An-Nizâm al-Iqtishâdi fi al-Islâmi. Beirut: Darul
Melalui karyanya berjudul: Islamic Law of Business Organization (Corporation), Nyazee mencoba menawarkan sebuah gagasan fundamental mengenai pentingnya Islamisasi dalam bidang korporasi modern. Kalau institusi finansial saja bisa dikonversi sesuai prinsip-prinsip syari'ah, mengapa korporasi tidak? Pemikiran ini merupakan kelanjutan dari kritikan Nyazee terhadap penerimaan konsep limited liability dan badan hukum oleh sebagian ilmuwan Muslim yang cenderung terburuburu. Meskipun demikian, dia masih menghargai upaya mereka, terutama dalam Islamisasi bisnis perbankan dan ekonomi Islam secara keseluruhan. Untuk menegaskan pendapatnya tersebut, Nyazee mengedepankan dua prinsip utama, yaitu larangan riba dan al-kharâj bi al-damân untuk mengaplikasikan prinsip-prinsip syari'ah dalam bisnis modern. Meskipun asumsi-asumsinya masih bersifat umum, namun gagasan Nyazee tentang Islamisasi di bidang korporasi merupakan pemikiran yang penting untuk ditindak lanjuti.

\section{Ummah}

As-Sabatin, Yusuf Ahmad Mahmud.2002. Al-Buŷे' al-Qadîmah wa al-Mu'âshirah wa al-Burshat al-Mahalliyyah wa ad-Duwaliyyah. Beirut: Darul Bayariq

Ash-Shiddiqy, Muhammad Hasbi. 2001. Pengantar Fiqh Muamalah. Semarang: Pustaka Rizki Putra

Financial Accounting Standards Board. 1994. Objects and Concepts of Financial Accounting, Presentation and General Disclosure Standart and Information about the Organization. Jeddah: tp

Islamic Fiqh Academy. 1992. Majma' al-Figh al-Islâmî. Jeddah: tp

Husein, Syahatah \& Fayyadh, Athiyahdan. 2004. Bursa Efek: Tuntunan Islam dalam Transaksi di Pasar Modal. Surabaya: Pustaka Progresif

Karim, Adiwarman A. 2004. Bank Islam: Created with 
10 I de Jure, Jurnal Syariah dan Hukum, Volume 3 Nomor 1, Juni 2011, hlm. 1-10

Analisis Figh dan Keuangan. Jakarta: Rajawali Press

Kelsen, Hans. 1945. General Theory of Law and State. Tp: Trans Wedberg

Nyazee, Imran Ahsan Khan. 1998. Islamic Law of Business Organization (Corporation). Pakistan: The International of Islamic Thought

Posner, Richad A. t.th. Economic Analysis of
Law. Boston: Little, Brown and Company

Siahaan \& Manurung. 2006. Aktiva Derivatif: Pasar Uang, Pasar Modal, Pasar Komoditi, dan Indeks. Jakarta: Elex Media Komputindo

Usmani, Muhammad Taqi.1992. "The Principle of Limited Liability From the Shariah Viewpoint", New Horizon 